\title{
PRACTICES OF BROADCAST MEDIA USAGE IN THE AGE OF NEW MEDIA: EVIDENCE FROM UGANDA
}

\author{
Yeni Medya Çağı Çerçevesinde Uganda'da Yayın Medya Kullanım Pratikleri * \\ Rajab Idd MUYINGO ${ }^{1}$ \\ Department of Radio, TV and Cinema, Marmara University - Turkey \\ 0000-0003-2857-8659 \\ Doç. Dr. Ali Murat KIRIK² \\ Department of Radio, TV and Cinema, Marmara University - Turkey \\ 0000-0002-5771-4843
}

\begin{abstract}
The impact of new media is felt everywhere in the world and it has resulted to radical changes in the broadcast media industry. The usage of new media has improved globally and African countries in particular have witnessed too the impact of new media. This study investigated practices of broadcast media usage in the age of convergent new media technologies and the impact of these patterns among the Ugandan youths. We employed both quantitative and qualitative methodologies. A total $\mathrm{N}=16$ was interviewed and $\mathrm{N}=486$ questionnaires were analyzed. All participants in this study were university students enrolled for the academic year 2019/2020 at two campuses, of the Islamic University in Uganda. Results show that mobile telephone is the most used tool of communication with an overall of $52.7 \%$ of the respondents spending more than 7 hours on telephone in a day. Yet $47.9 \%$ spent 1 to 3 hours watching TV daily. Radio was the least used media platforms as they spent less than one hour listening to radio. The study further exposed that $92.8 \%$ of the sample population possessed mobile phones and listened to radio through it. The second most accessed and possessed device used in the reception of radio and TV was smartphones with $80.7 \%$ whereas TV sets were accessed by $70 \%$ of the informants and $69.1 \%$ revealed that they owned a radio set at their residence. The least accessed device were laptops and desktop where by only $47.7 \%$ accessed them. Possession of media devices was strongly correlated with the monthly income of the respondents, both at value $\mathrm{P}=.004$ and $\mathrm{P}=$ .000 respectively. The study concluded that there is a paradigm shift in the usage of radio and TV from traditional reception to new media reception.
\end{abstract}

Key Words: Practices, Radio and Television, New Media, Uganda, Youths

Öz: Yeni medya dünyanın her noktasında etkisini hissettirmiş ve ülkelerde köklü değişimleri medyana getirmiştir. Dünyada yaygın bir kullanım alanına ulaşan yeni medya Afrika ülkelerinde de etkisini hissetirmiştir. Bu araştırma, Uganda gençliğinin yeni

\footnotetext{
* This article titled "Practices of Broadcast Media Usage in The Age of New Media" was extracted from my PhD thesis.

* Type: Research Article

${ }^{1}$ e-mail: rajabmuyingo@marun.edu.tr

2e-mail: murat.kirik@marmara.edu.tr
} 
medya teknolojilerini kullanım pratikleri ve yeni medyanın Uganda'daki etkisini belirlemeyi amaçlamaktadır. Çalışmada hem nicel hem de nitel araştırma yöntemleri kullanılmıştır. 16 öğrenciyle yüz yüze mülâkat gerçekleştirilmiş, ayrıca 486 öğrenciye ise anket tekniği uygulanmıştır. Ankete Uganda'daki İslam Üniversitesi'nin iki kampüsünde 2019-2020 akademik yılında eğitimlerine devam eden öğrenciler katımıştı. Araştırma sonuçları incelendiğinde, katılımcıların çoğunluğunun \% 52,7 oranla cep telefonunu birincil derecede tercih ettiği görülmüştür. Ayrıca günde 7 saatten fazla telefonla vakit geçirdikleri tespit edilmiştir. Yine de \% 47,9'luk bir oran günde 1 - 3 saat arasında TV izlemektedir. Radyo dinleme oranları gençler arasında oldukça düşük bir orandadır. Ayrıca, sonuçlara göre \% 92, $8^{\prime}$ lik bir oranın cep telefonlarına sahip olduğu ve bu telefonlar aracılığıyla radyo dinlediği görülmüştür. Bununla birlikte radyo ve TV programlarına daha çok akıllı telefonlar üzerinden erişilmektedir. İletişim araçlarına sahip olma, sırasıyla $P=.004$ ve $P=.000$ değerleriyle birlikte katılımcıların aylık geliri ile güçlü bir korelasyona sahiptir. Sonuç olarak, Uganda'da yeni medya teknolojilerinin gelişmesiyle birlikte geleneksel radyo ve TV cihazlarının kullanım pratiklerinin değiştiği ortaya çıkmıştır.

Anahtar Kelimeler: Pratikleri, Radyo ve Televizyon, Yeni Medya, Uganda, Gençler

\section{INTRODUCTION}

Since the inception of radio and television content delivery occurred in a one-way, sender to- receiver fashion, without the capability of obtaining rapid feedback and interaction from the audience (Lee, Lindsey, \& Kim, 2017). But the widespread adoption of social media, blogs, and smartphones has changed this process (Kim, Sunda \& Park, 2011). Equally, scholars further emphasize that new media technologies provide media consumers manifold options to handle and consume media content in different contexts and to easily share them with others (Ley, Ogonowski, Hess, Reichling, Wan \& Wulf, 2014). It is widely accepted now that new forms of information, communication, and media technologies have been influencing the daily life of people and considerably changing their behaviors and attitudes. For instance, mobile phones today are integrated into the daily life of the population and people have sometimes difficulties to live without them (Ley et al. 2014).

Likewise, the emergence of social media and the introduction of new ways of broadcast media distribution, especially IPTV, digital TV and radio reception technologies, the media consumption patterns have been changing considerably (Wei \& Lo, 2006). As more people access news through newer media platforms such as social media, and interact with journalists more directly through such venues, the ways in which people consume news likely to be changed. In explaining some new media technologies, (Hanley, 2014) observed that there are several new media technologies, for instance web-enabled devices (for instance, smartphones, game consoles, Smart TVs or tablet computers), video platforms (for example, YouTube) and social networks (like Facebook) available for individual media consumption. This media landscape continuously changes and influences the way people consume and interact with each other (Haridakis, 2002).

Further, Hanley (2014) stressed that social media have revolutionized the television viewership practices with new consumer demands and new ways of newsgathering and news distribution. For instance, through social media, television stations can stream content directly from their YouTube, Facebook, and Twitter accounts via an RSS feed, making it easily accessible for the audience to view content in one place. Likewise, (Kırık 2013; Raacke \& Bonds-Raacke 2008) added that social networking sites like Facebook, Twitter, Instagram, Youtube and Periscope attract individuals of all ages and all classes, where users interact by sharing photos, text, voice and data. It is worth noting that a partnership seems to have formed with television and social media, with each medium continuously enhancing the other one. Social media and television have become mutually beneficial to each other as departments have been dedicated to a web staff, anchors and reporters connect with their fan base via Twitter, and mobile devices have been added into the mix to keep viewers tuned in by the minute on breaking news and weather headlines (Hanley, 2014). 
Remarkably, media environment in developing economies to-date is far better than in 1960s; whereby almost every rural community is accessing at least one form of media as a way of accessing information (Kakonage, 2013). He also stressed that media has remained central in informing people about the socio economic and political development in all countries around the globe. Accordingly, media communication platforms in Africa have prompted new initiatives for development. For instance, in Zambia, where women's clubs dedicated to discussion, debate and feedback on women's issues, such as abortion and inheritance law, chose to broadcast their clubs' development related discussions over the airwaves (Kakonage, 2013).

Odongo (2012) emphasized that in Uganda, mass media remains the primary source through which the population get news and related information. In Uganda the country's development agenda is being transformed and people are more informed and eager to participate in development-related issues. Among the various media channels, radio still remains the major form of disseminating and receiving information by the rural population in Uganda (Odongo, 2012). Curiously, a few rural towns have connections to television, but with very minimal number of people getting information through TV, because they cannot afford it due to high levels of poverty. Despite that fact that majority of Ugandan rural audiences rely on radio for information, the media consumption patterns are steadily changing due to advancements in technology.

Researchers (Kim et al., 2011; Papacharissi \& Mendelson, 2007) contend that with the widespread adoption of social media for sharing and accessing news, as well as the possibility of news consumers' direct interactions with journalists through social media, currently the radio and TV content producers are confronted with the customers' demand to enable media consumption on various devices including radio, TV, mobile phone, in-car entertainment and personal computers (Lee, Lindsey, \& Kim, 2017). But despite the large number of studies reported in the literature, our understanding of the impacts of new media technologies on broadcast media usage and social behavior of the youths is still limited in the Ugandan context. Therefore, the aim of this study is to increase our understanding about the relationship between this fast progressing new media technologies and the broadcast media usage practices; especially the devices and platforms used for accessing radio and television content, program preferences and motivations for listening to radio and watching television programs.

This study attempted to answer the following research questions; The main question is;

How have the broadcast media usage practices of the Ugandan youths Changed in the age of new media?

\section{Sub questions are:}

a) What devices \& platforms do they prefer to access radio and TV programs?

b) What is the daily media usage rate $\&$ which program are they much interested in?

c) What is the motivation of the respondents for listening to radio \& watching TV Programs?

d) What is the relationship between broadcast media usage patterns and the demographic characteristics of the respondents?

\section{Literature Review}

One of the early studies on traditional television viewing was done by Lull (1991) in the 1980s, and discovered social practices of behavior in families when watching television in the living room. To him, television can nurture interpersonal relationships, e.g. by having a common topic to talk about. Nevertheless, new technologies have changed the once simple act of watching broadcast television in several respects. Nowadays, television is embedded in a video media lifecycle process (Wei \& Lo, 2006). Whereby watching television today means much more 
than the just the simple consumption of planned programmes (Papacharissi \& Mendelson, 2007); it facilitates a number of possible functionalities related to searching, obtaining, sharing, collecting, and discussing the viewed content. New technologies such as streaming portals on the Internet support these processes and have changed the way in which users watch television (Barkhuus \& Brown, 2009).

In the same way, Smith and Krugman (2010) investigated these practices with regards to established consumption patterns and how users perceive changes in their media usage. They found that personal hard-disk video recorders lead to a more flexible and controllable TV consumption, which makes the user's viewing behavior more convenient (Haridakis, 2002). Therefore, a typology of influential factors has been deduced from the existing models of watching television. The factors that influence and change viewing habits fall into four categories: individual characteristics, programme. Applying these factors when investigating existing phenomena can help clarify television watching behavior in the new technology era (Conway \& Rubin, 1991).

Researchers (Hermida, 2010; Holton \& Chyi, 2012) found that frequent uses of social media such as Twitter and Facebook as news sources causes perceived information overload, which in turn facilitates cognitive elaboration of news information. Consequently, the level of perceived news information overload may influence news consumers' perceptions of news quality (Zeng 2011; Wei \& Lo, 2006). Furthermore, depending how they react to perceived news information overload, consumers' perceptions of news quality may vary. Scholars further adds that when news consumers actively manage news information overload by engaging in cognitive processing, there may be positive perception of news quality as shown by the increased perception of source credibility (Westerman, Spence, and Van Der Heide, 2014). Consumers may evaluate journalists encountered on social media as more competent, good willed, and trustworthy as they actively process the news information. On the other hand, if consumers do not engage in cognitive processing and avoid news altogether rather than selectively exposing themselves to certain sources (i.e., managing the information), they may perceive the quality of news more negatively (Westerman et al, 2014).

Nevertheless, though the role of radio and television as an important source of information, relaxation and entertainment has remained the same, technological developments have changed the way it is used (Wei \& Lo, 2006; Zeng 2011). The relationship between this fast progressing new media technologies and the broadcast media usage practices; especially the devices and platforms used for accessing radio and television content, program preferences and motivations for listening to radio and watching television programs is changing day in day out. Scholars Ley et al. (2014) adds that broadcast media, especially television as a traditional mass medium is influenced by new technological developments. Currently, new transmission standards and bi-directional technologies means that television usage can be decoupled from the traditional broadcast schedule. Scholars (Kim et al., 2011; Barkhuus and Brown 2009) reveal that television content can be accessed on different devices and in order to get additional information on a TV show, it can be complemented by on-demand services on the internet. This has made TV users to have several options of what they want to watch and when. Currently, the second screen devices (namely, smartphones; tablets) can be used to retrieve personalized content and to interact with others, e.g. in order to catch up on the TV programme or to communicate with others via instant messenger simultaneously (Bernhaupt 2010; So 2012).

The development of internet and its subsequent technologies have played a significant role in the transition from Mass Media towards Networked Media and this transition has directly influenced broadcast usage practices (Nauman, 2017). Accordingly, new forms of technological features encourage different communicative practices such as social media that have increasingly become "interactive, hypertextual, virtual, and networked (Kasadha, 2020). It's worth noting that the increase in use of social media and portable touchscreen devices (e.g. 
smart phones, tablets, etc.) have given television program viewers the ability to interact in real-time, even if they do not share a proximal physical space (So, 2012). Similarly, Nauman (2017) found that in Pakistan, almost $99 \%$ of the university students had mobile phones. Likewise, the introduction of $3 \mathrm{G}$ and $4 \mathrm{G}$ mobile technologies in 2014 and ICT policy initiatives suggests that there were plans to subsidize smart phones in the country, which would further boost the digital environment. This made broadcast media users in Pakistan to have more choices to follow news from multiple platforms and via multiple devices.

Nevertheless Barkhuus \& Brown (2009) emphasizes that the result for such technological developments has been that an increasing number of people turning to their "second-screen" devices to share their reactions to television shows instantly through Social TVand other new media platforms. Television viewers in this situation use social networking sites (e.g. Facebook, Twitter, etc.) to discuss the television program shortly before, during, or after the program airs. Other researchers (Ainasoja et al., 2014; Giglietto and Selva, 2014) accentuated that within such an experience, viewers devote one screen to watching the television program while dedicating another (typically a smart phone, tablet, or laptop) to concurrently communicating with others about the television program.

While radio listenership in Uganda's rural areas and viewership of traditional live TV still dominates in Uganda among urban populations, there is a paradigm shift of electronic media usage among the Ugandan citizens (Kasadha, 2020). According to Uganda Communications Commission's Quarterly Statistics Report (2017), internet penetration per 100 citizens in Uganda was observed at 51.9, a figure that indicates that more than half of each 100 citizens used internet. In comparison with the above mentioned 2014 statistics on internet usage in Uganda, the number of estimated internet users has increased to 19 million in the year 2016, leading to over 61.7\% mobile internet subscription recorded from third to fourth quarter in the year 2016 (UCC, 2017). The increased mobile internet subscriptions are assumed to increase the use of social media and reception of Radio and TV through new digital platforms.

\section{Theoretical Framework}

Theoretically, a study that examines the relationship between audiences and the media they consume espouses in the uses and gratification theoretical framework (Ruggiero, 2000). Research inquiries into the reasons why people use the mass media and the gratifications derived from media use date back over 40 years. In exploring the functions of the media and the role of audience members' needs and expectations in mass communication behavior, earlier investigations formulated typologies of radio and newspaper use (Rubin, 1981). Accordingly, West \& Turner (2010) emphasized that theorists Katz, Blumler, and Gurevitch in 1974, presented a systematic and comprehensive articulation of audience members' role in the mass communication process, in the realm of the uses and gratification theoretical framework. This theory holds that people actively seek out specific media and specific content to generate specific gratifications or results, (West \& Turner 2010; Barkhuus \& Brown 2009). Theorists in Uses and Gratifications view media users as active because they are able to examine and evaluate various types of media to accomplish communication goals.

Since the current study examines practices of broadcast media usage in the new media era, researchers in Uses and Gratifications Theory namely Katz, Blumler, \& Gurevitch, ask the question, what do consumers do with the media? Therefore, this audience-centered media theory underscores an active media consumer with the following assumptions clearly articulated by the founders of the approach. They contend that there are five basic assumptions of Uses and Gratifications Theory; 1) The audience is active and its media use is goal oriented. 2) The initiative in linking need gratification to a specific medium choice rests with the audience member. 3) The media compete with other sources for need satisfaction. 4) People have enough self-awareness of their media use, in- 
terests, and motives to be able to provide researchers with an accurate picture of that use. 5)Value judgments of media content can only be assessed by the audience (West \& Turner, 2010).

Scholars in Uses and Gratifications argue that because it is individual audience members who decide to use certain content for certain ends, the value of media content can be assessed only by the audience. For instance, studies conducted by (Rubin 1981; Sundar \& Limperos, 2013) found that motivations for television use were clustered into the following categories: to pass time, for companionship, excitement, escape, enjoyment, social interaction, relaxation, information, and to learn about a specific content. Whereas researchers, Swart, Peters, \& Broersma, (2016) asserted that media use could be categorized with only four basic divisions: diversion, personal relationships, personal identity, and surveillance.

Furthermore, Fiske, J. (2002) asserts that this approach takes as its basis the belief that the audience has a complex set of needs which it seeks to satisfy in the mass media. There are, of course, other ways of satisfying needs-holidays, sport, hobbies, work, etc. This theory was developed to explain mass communication, though it fits very well with theories of face-to-face communication which postulate that we use social relationships to satisfy personal needs and drives. This model of communication assumes an audience that is at least as active as the sender. It also implies that a message is what the audience makes of it, not what the sender intends, and thus has some similarity with the semiotic method (Conway \& Rubin, 1991).

In their study of the audience of television, (Swart, Peters \& Broersma, 2016) found amongst other things, that there were groups of broadly similar 'uses' that people made of television quiz programmes. Most of the audience used quiz programmes for four main gratifications: self-rating, social interaction, excitement, and education. We might speculate that they were using the media to give themselves a personal status which their social life did not. This is a clear example of the compensatory use of the media to gratify needs that the rest of social life frustrates. It's worth noting that, audiences report various motivations for media use. These sometimes include such things as passing time and learning about things or oneself, as well as for arousal, relaxation, companions and because of a habit (Perry 2002; Sundar \& Limperos, 2013)

Basing on the above theoretical framework, we assumed the following hypotheses for this study;

a) H1. The study predicts that practices for broadcast media usage of the Ugandan youths have changed due to the emergence of the new media technologies.

b) $\mathrm{H} 2$. It predicts that there is relationship between media usage patterns and the demographic characteristics of the respondents.

c) H3. The study predicts that the motivations for watching television will be similar to Rubin's (1981) motivations for watching television- Relaxation and escapism; Knowledge or learn about current event; - Companionship and to be able to socially interact; Entertainment and enjoyment; Insight and information.

\section{Methodology}

The research methodology usually presents the type of research design used, the basic process by which research study was conducted, the research-related considerations of which researchers should be aware, the manner in which the results of research can be interpreted and disseminated, and the typical pitfalls faced by researhers when designing and conducting a research study (Marczyk, DeMatteo \& Festinger, 2005). Basing on the nature and the objectives of the study, we adopted a mixed method research where both quantitative and qualitative mechanisms were employed. 
The universe of this study encompassed population of young adults in Uganda who make up 21\% of the whole population, where about $72 \%$ of young people or youth aged between $15-29$ years (UBOS, 2018). The sample of this study was university youth enrolled at the two campuses of the Islamic University in Uganda in the 2019/2020 academic year. During the survey, both questionnaires and interviews were used as tools for data collection on a randomly selected sample of the university youths in Uganda.

Survey research is relevant for the current study as Frey \& Cissna (2009) justifies, it ascertains the beliefs, attitudes, values, or behaviors of a population of interest from a sample of respondents selected from that population. Survey research, thus, is important in applied communication in exploring communicative behaviors, with the overarching goal of understanding practical problems and issues across a variety of applied settings.

The main instrument for quantitative data collection was the questionnaire, designed in the Likert scale format with close ended questions. A total 486 questionnaires were completed making response rate of (79.2\%). For the statistical analysis of quantitative data, we extracted data of 486 participants from the questionnaires to SPSS version (23) for the analysis. Frequency distribution and percentages were used to summarize demographic characteristics of respondents, in this case, age and sex. The Chi-Square analysis was employed to determine the relationship between different variables. Equally, factor analysis was used to synthesize more succinct, grouped categories and summarize relationships. Whereas only 16 informants participated in the face-to-face interview due to unpredictable study limitations. Data collected through interviews was analyzed using content analysis technique. Within the case study analysis of the interviews, researchers analyzed the voices of each interviewee under the study major factors/themes.

Although findings of this study could be generalized on the Ugandan audience, but due to the study limitations, all participants in this study were university students enrolled for the academic year 2019/2020 at two different campuses, of the Islamic University in Uganda namely the main campus located in Mbale town in Eastern Uganda and Kampala campus located at Kibuli, Kampala in central Uganda. The majority of 58.2\% were from the main campus located in Mbale, yet $41.8 \%$ were from Kampala campus.

\section{Findings and Interpretation}

The principle aim of this study is to understand practices of broadcast media usage among the Ugandan youths in the age of convergent new media technologies and the impact of these patterns. It's worth reporting that 283 of the participants in this study were male constituting of (58.2\%) whereas 203 were female who made up of $(41.8 \%)$ respectively. Equally, the majority were at the Bachelor's degree level with a representation of 311 participants (64\%), followed by those at the Post-Secondary level with 103 participants (21.2\%) and lastly those at Masters and Doctorate level were few composing of 72 respondents (14.8\%) respectively.

Nevertheless, hypothesis one of this study stated that practices for broadcast media usage of the Ugandan youths have changed due to the emergence of the new media technologies. We tested this hypothesis using descriptive statistics and we found that mobile telephone is the most used tool of communication with an overall of $52.7 \%$ of the respondents spending more than 7 hours on telephone in a day. Similarly, $51.0 \%$ of the respondents exposed that they spent 7 hours and more while using internet for general purposes like research, information and entertainment. Yet, $45.5 \%$ reported that they spent around 4 to 6 hours daily on social media. Hitherto 47.9\% of the sample spent 1 to 3 hours watching TV daily. Radio and Newspapers were the least used media platforms. For newspaper they had no regular readership pattern and they spent less than one hour listening to radio. This implies that with the emergence of new forms of communications especially social media, people pay less attention to traditional radio and TV broadcasts due to the availability of multiple sources of entertainment 
and information.

The study further exposed that $92.8 \%$ of the sample population of this research had mobile phones and $83.7 \%$ confirmed to own only one mobile hand set. The second most accessed and possessed device used in the reception of radio and TV was smartphones with $80.7 \%$ whereas TV sets were accessed by $70 \%$ of the informants and $69.1 \%$ revealed that they owned a radio set at their residence. The least used devices for accessing radio and TV signals were laptops and desktop where by only $47.7 \%$ accessed radio and TV through them. Mobile and smart phones are the most used new media devices for accessing radio and TV programs with representation of $79.2 \%$ and $60.1 \%$ respectively. Meanwhile $64.6 \%$ never used laptops at all and $79.2 \%$ never used desktops to access radio and TV programs. Similarly, tablets and smart watch (i-Watch) were the least used devices.

Therefore, in line with hypothesis one above we confirmed with this study findings that the integration and availability of new media technologies has enriched the media usage globally and in Uganda in particular hence has had multiple effects on the way in which young people interact with broadcast media content in forms of how they access, use and interact with it, as elaborated further in chat 1 below;

Pie Chat 1 Showing mode of accessing TV and Radio Programs via Online Platforms

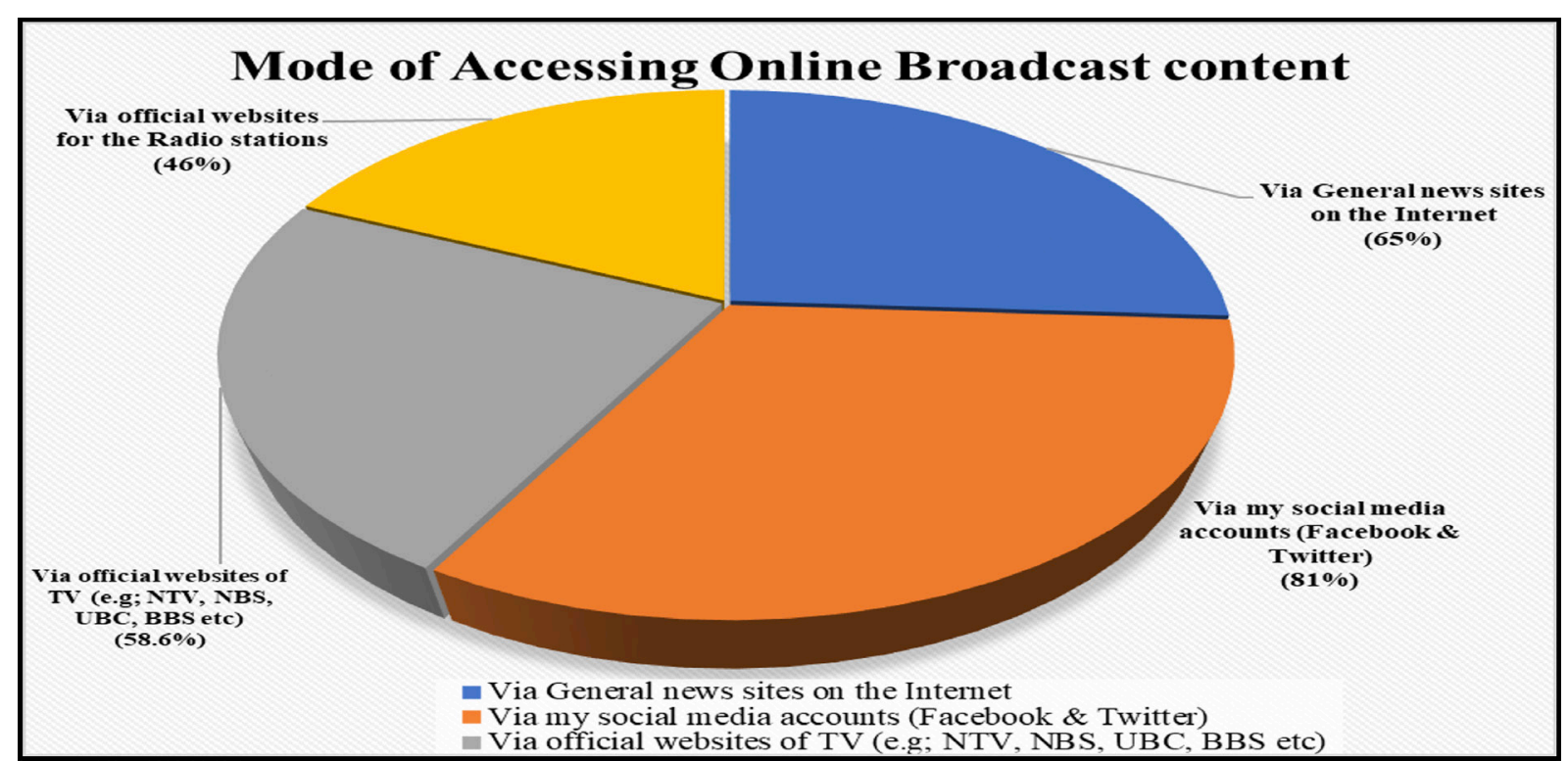

From the interviews, we found out that there is also a shift in the usage of radio and TV due to technological changes, that is from receiving radio and TV programs from radio and TV sets to other gadgets. For instance, many respondents reported that they access radio and TV programs through smart phone. Whereas one informant stated that "... I use radio set during day time and use mobile phone at night bed time to access radio programs. This is convenient for me while listening to radio at night." Additionally, another respondent said "At school; I uses phone, while at home I use radio set to access radio programs. Its so fun for me". Other devices used in accessing radio programs was MP3 player, as noted by the respondents.

Meanwhile, in confirmation with hypothesis two which predicted that there is relationship between media usage patterns and the demographic characteristics of the respondents, results of this research indicate that watching TV, mobile telephone usage and general usage of internet were significantly and positively correlated 
with the learning institutions of the participants. For the time spent by the participants while watching TV, the ( $r=.126, p=.005)$ value specifies that watching TV was significantly associated with the campuses where sample of the study were drawn. Moreover, this study found that both mobile phone usage and general usage of internet were significantly correlated with the institution of learning at values of $(r=.189, p=.000)$ and $(r=.262, p=.000)$ respectively, which signified a strong correlation. This strong correlation further attributed to the divergence of the respondents' geographical location of their institutions, where by one institution is located in Kampala, the capital city of Uganda whereas the other is upcountry in Mbale, eastern Uganda. However, the study did not establish any significant correlation between gender of the respondents and time spent on different media. This implies that both male and female respondents used media equally.

Additionally, we also observed that radio listenership was significantly associated with demographic characteristics of the respondents. For instance, there was a strong and positive correlation between radio listenership and marital status at value of $(r=.155, p=.001)$, this however implies that there is difference in radio listenership between respondents according to their marital status whether single, married or other categories. Similarly, there was a strong and positive correlation between radio listenership and age of the respondents at value of $(r=.130, p=.004)$, this infers that there is dissimilarity in radio listenership among people of different age groups. However, radio listenership was significantly and negatively associated with the educational level of the participant at value $(r=-.117, p=.010)$. However, social media usage, newspaper readership and time spent on mobile telephone were also not significantly correlated with any demographic characteristic of the respondents. It's worth to point out that possession of devices used in accessing radio and TV signals namely; radio and TV sets, mobile telephone, laptops and desktop was strongly correlated with the monthly income of the respondents, both at value $\mathrm{P}=.004$ and $\mathrm{P}=.000$ respectively. This implies that those with high income possessed one or more devices whereas those with lower income did not possess any, hence making it difficult for them to access radio and TV programs.

Hypothesis three stated that; motivations for watching television will be similar to Rubin's (1981) motivations for watching television- Relaxation and escapism; Knowledge or learn about current event; - Companionship and to be able to socially interact; Entertainment and enjoyment; Insight and information. In line with this hypothesis, we found four main motivations for watching TV which are a bit different from those of Rubin's (1981). These were, information needs, relaxation; entertainment and companionship.

To synthesize more succinct and grouped categories comprised of motivations for watching TV, we applied factor analysis to the data. Factor analysis can be used to summarize relationships in the form of a more parsimonious set of factor scores that can then be used in subsequent analyses e.g., analysis of variance, regression, or descriptive discriminant analysis (Thompson, 2004). Factor analysis has been characterized as one of the most powerful methods yet for reducing variable complexity to greater simplicity and as the furthest logical development and reigning queen of the correlational methods.

Initially, respondents indicated their levels of agreement with 16 statements of motivations for watching television across five response options, ranging from "strongly agree" to "strongly disagree" like their own reasons for viewing traditional television broadcast. This analysis is an assessment of general television use motivations, reflecting a desire to view certain program content over others. Patterns of viewing motivations were determined by conducting a principal factor analysis with iterations and oblique rotation. Oblique rotation was utilized recognizing that viewing motivations are interrelated. Whereas "orthogonality imposes independency on a structure," oblique analysis "rotates all factors in hyperspace with one another in search of the best hyperplanes describing a construct (Rubin, 1983). 
Nevertheless, we clustered all options under four headings as; information needs, relaxation; entertainment and companionship. The results of the Factor Analysis are shown in Table 1. Therefore, we found out that participants generally watch TV broadcasts for four main reasons: for general Informational needs, for relaxation, for enjoyment and for companionship and socializing.

The factor solution, which identified four initial factors, explained 56.9\% percent of the total variance. Factor 1 (Information need) had an eigenvalue of 1.13 and explained 4 percent of the common variance. The first factor information need, had eight reasons clustered under it. The four reasons with the large positive loading on the factor and with highest values are 'it makes me feel less lonely' (.702), it lets me choose when to watch favorite program (.674), it allows me to talk to others about a TV show (.664) and it makes me knowledgeable, get and gain new information (.653). The data indicates that Ugandan university students who participated in this study are interested in national and international level news. It also shows that they were frequently accessing information about the current happenings at an international level. The fifth most popular reason for watching TV was to connect with other characters.

The second factor was relaxation. This factor comprised of two responses. These were, it lets me forget about other responsibilities (.623) had large positive loadings on factor whereas those who watch TV as a habit, just something they do to relax (.575), had the least value in this factor. The third factor was enjoyment. This factor comprised of three responses. Namely, it passes the time when I am bored (.593), to feel in control of what I am watching (-.523) and it's convenient to see shows when I want (.513), these responses had large positive loadings on factor 3 , so this factor describes enjoyment as motivation for the participants to watch TV. The fourth factor was companionship as a general motivation for watching TV. However, this factor had only two responses, namely it's for companionship and social interaction (.558) whereas for entertainment and enjoyment had factor loading of (.466) respectively.

Table 1: Showing Factor Analysis for Motivations of Watching TV

\begin{tabular}{|c|c|c|c|c|}
\hline \multicolumn{5}{|c|}{ Component Matrix } \\
\hline \multirow[b]{3}{*}{ Components } & \multicolumn{4}{|c|}{ FACTORS } \\
\hline & Information & Relaxation & Enjoyment & Companion \\
\hline & & & & \\
\hline It makes me feel less lonely & .702 & -.335 & .231 & -.141 \\
\hline I can choose when to watch my favorite Prog & .674 & .153 & -.001 & -.043 \\
\hline It allows me to talk to others about a TV show & .664 & -.198 & -.056 & -.206 \\
\hline It makes me knowledgeable, get $\&$ information & .653 & -.287 & -.036 & -.185 \\
\hline It allows me to plan a TV program around & .598 & -.141 & .056 & -.442 \\
\hline I watch broadcast TV purely to relax \& escape & .527 & -.205 & .158 & .336 \\
\hline It allows me to connect with other characters & .505 & .186 & -.432 & .175 \\
\hline To plan my schedule a round a TV program & .497 & .233 & -.449 & -.338 \\
\hline It lets me forget about other responsibilities & .365 & .623 & -.097 & -.140 \\
\hline It's a habit, just something I do & .077 & .575 & .365 & -.268 \\
\hline It passes the time when I am bored & .497 & -.117 & .593 & -.008 \\
\hline To feel in control of what I am watching & .516 & .184 & -.523 & .297 \\
\hline It's convenient to see shows when I want & .304 & .468 & .513 & .155 \\
\hline
\end{tabular}




\begin{tabular}{|l|r|r|r|r|}
\hline It's for companionship and social interaction & .501 & -.312 & .013 & .558 \\
\hline For entertainment and enjoyment & .320 & .438 & .143 & .466 \\
\hline Extraction Method: Principal Component Analysis. \\
\hline a. 4 components extracted.
\end{tabular}

Basing on the interviews, we found out that majority of the informants watch TV majorly for two reasons, that is for information and entertainment purposes. Eight (08) participants unanimously stated that "we watch TV to get news and information so that we can know what is going on around the world. I prefer news, health and political program so that I am updated on the current affairs and politics both locally and internationally". Similarly, six (6) respondents pointed out that...It's a fun to watch TV. It's entertaining and I like watching TV series like Telemondo- Big brother. I like soaps and music programs too. Additionally, other participants also mentioned that they watch TV programs like game on extra on Urban TV and supper sport matches accordingly. These two motivations however, are part of the above motivations found in the factor analysis and partially in line with (Rubin, 1983) motivations

\section{DISCUSSION AND CONCLUSION}

Technological infrastructure at home is changing continuously and is becoming increasingly interconnected. Media devices, including the TV set, smart and mobile phones provide access to the Internet and offer manifold opportunities to consume media on demand and also enable flexible consumption and sharing of broadcast media content. The purpose of the study was to examine the relationship between these fast progressing new media technologies and the broadcast media usage practices; especially the devices and platforms used for accessing radio and television content, program preferences and motivations for listening to radio and watching television programs alongside new media platforms. This study exposed that Mobile and smart phones were the most used new media devices for accessing radio and TV programs with representation of $79.2 \%$ and $60.1 \%$ respectively. Whereas the least used devices for accessing radio and TV signals were laptops and desktop where by only $47.7 \%$ accessed radio and TV through them. Respondents spent 7 hours and more while using internet for different purposes like research, information and entertainment whereas $45.5 \%$ spent around 4 to 6 hours daily on social media. Therefore, the relationship between this fast progressing new media technologies and the broadcast media usage practices; especially the devices and platforms used for accessing radio and television content, program preferences and motivations for listening to radio and watching television programs is changing day in day out.

Exclusively, television as a traditional mass medium is influenced by new technological developments, as (Auverset 2017; Kim et al., 2011) notes that the increase in use of social media and portable touchscreen devices (e.g. smart phones, tablets, etc.) have given television program viewers the ability to interact in real-time, even if they do not share a proximal physical space. In this study we found that TV sets were less accessed by the informants and many owned at least a radio set at their residence. As $47.9 \%$ of the sample spent 1 to 3 hours watching TV daily via TV sets. Radio and Newspapers were the least used media platforms and they spent less than one hour listening to radio. These findings imply that with the emergence of new forms of communications especially social media, people pay less attention to traditional radio and TV broadcasts due to the availability of multiple sources of entertainment and information. This further means that the integration and availability of new media technologies has enriched the media usage globally and in Uganda in particular hence has had multiple effects on the way in which young people interact with broadcast media content in forms of how they access, uses and interact with it. These findings however, are supported with previous studies of (Ley et al. 2014) who echoed that though the role of radio and television as an important source of information, relaxation and entertainment has remained the same, technological developments have changed the way they are used. 
Equally, findings from the factorial analysis supported $\mathrm{H} 3$ that stated that the motivations for watching television will be similar to Rubin's (1981) motivations for watching television- Relaxation and escapism; Knowledge or learn about current event; - Companionship and to be able to socially interact; Entertainment and enjoyment; Insight and information. The tested variables in the factor analysis registered $\mathrm{KMO}=.750$, above the commonly recommended value of .6, and Bartlett's test of sphericity was significant $(\chi 2[38]=5,501.36, p<.001)$, with the factorial solution of $56.9 \%$ of the total variance. Therefore, the $56.9 \%$ variance of factors was the highest in explaining the correlation between tested variables. The eigenvalues indicated the four factors (motivations for watching TV) as; information needs, relaxation; entertainment and companionship. Therefore, to a greater extent the reasons why Ugandan youths watch TV as per the factor analysis results were similar to Rubin's (1981) motivations for watching TV. Although Rubin had five motivations, in our study categorically we found four reasons for watching TV. The missing motivation in our study was Knowledge or learning about current event, and the remaining four motivations were similar. Meanwhile, motivations for listening to radio observed from the qualitative findings included, entertainment purposes like through listening to music and songs, and information needs, especially through news (current affairs), educational programs, religious, health, and political radio talk shows.

It's worth to stress that though in the early days of radio and television, content delivery occurred in a one-way, sender to- receiver fashion, without the capability of obtaining rapid feedback and interaction from the audience (Ley et al., 2014), but the widespread adoption of new media technologies especially web-enabled devices for instance, smartphones, Smart TVs or tablet computers, video platforms for example, YouTube and social networks like Facebook (Ley et al. 2014) have changed the process of radio and TV content delivery and reception. Undoubtedly, these new forms of information, communication, and media technologies have been influencing the daily life of people and considerably changing their behaviors and attitudes hence providing radio and TV users manifold options to handle and consume broadcast content in different contexts and to easily share them with others.

The emergence of new media technologies especially social media and the introduction of new ways of broadcast media distribution, particularly IPTV, digital TV and radio reception technologies, have made the broadcast media landscape to continuously change and influence the way people consume radio and TV programs and interact with each other. As per our results people can now access radio and TV news updates through newer media platforms such as social media, and interact with journalists more directly through such venues, as opposed to the early days of radio and TV. Social media have also revolutionized the television viewership practices with new consumer demands and new ways of newsgathering and news distribution. Through social media, television stations can stream content directly from their YouTube, Facebook, and Twitter accounts, making it easily accessible for the audience to view content in one place.

Conclusively, the argument that new media platforms will replace old ones requires revision. Currently no old media exists today. The current, so-called traditional media such as television and radio have evolved into the modern form of their older versions. Their working dynamics are not carried out in the way it used to be carried out in the past. For instance, TV has been upgraded technologically and has become more interactive. Television audiences use smart television or consume television content via social media. In the light of this context and based on the results of this study, we can conclude that partial replacement as well as full displacement is a reality. Technology indeed is a critical contributor which exerts a fundamental influence on the patterns of broadcast media usage but it also contributes in shaping up of the cultural, political, social and economic knowledge dissemination. Hence making practices of broadcast media usage dependent on all these technological, cultural, political, and economic factors. 
In order to further understand the dynamism of the broadcast media in the digital era in Uganda, we recommend that future studies should focus on broadcast media usage patterns in the new media age within diverse groups of population to understand the broader picture of the broadcast media usage landscape. Additionally, data collected from university students should be repeated at least every three to five years to gain a longitudinal perspective on broadcast media usage practices of university students in Uganda. Finally, there is a need to conduct more focused studies, particularly in the African contexts, to understand social and cultural change and the impact of technology on the broadcast news usage experience. 


\section{REFERENCES}

Auverset, L., A. (2017). Social TV is the New Digital Watercooler: Personality Traits, Behaviours, and Trends in Second-Screen Media Activity. Dissertation. The University of Alabama. USA.

Barkhuus, L. and Brown, B. (2009). Unpacking the television: user practices around a changing technology. ACM Transactions on Computer-Human Interaction (TOCHI), 16 (3), 1-22.

Bernhaupt, R. (2010). Ethnographic insights on security, privacy, and personalization aspects of user interaction in interactive TV. Proceedings of the 8th international interactive conference on interactive TV \& videoEurolTV'10. New York, NY: ACM Press, 187-196.

Conway, J. C., \& Rubin, A. M. (1991). Psychological predictors of television viewing motivation. Communication Research, 18, 443-463. doi: 10.1177/009365091018004001

Fiske, J. (2002). Introduction to Communication Studies. 2nd Ed, London: Taylor \& Francis.

Frey, L. R., \& Cissna, N. K. (2009). Routledge Handbook of Applied Communication Research. $\quad$ New York: Taylor and Francis

Hanley, K. (2014) The New Newsroom: The Impact of Digital and Social Media on Local Television News Stations. (Master's. Thesis), Drexel University, USA.

Haridakis, P. M. (2002). Viewer characteristics, exposure to television violence and aggression. Media Psychology, 4, 235-353. doi: 10.1207/S1532785XMEP0404_02

Hermida, A. (2010). Twittering the news. Journalism Practice, 4(3), 297 e308.

Holton, A. E., \& Chyi, H. I. (2012). News and the overloaded consumer: Factors influencing information overload among news consumers. Cyberpsychology, Behavior, and Social Networking, 15(11), 619e624.

Kakonage, J. (2013). The Role of The Media in Africa's Development: From Vision To Reality. Global Media Journal, African Edition, 7(2):172-180.

Kasadha J. (2020). Does social media matter in developing democracies? Examining its impact on citizen political participation and expression in Uganda. Journal of Public Affairs. https://doi.org/10.1002/ pa.1981

Kırık, A. (2013). Conversion From Television To Internet In Turkey And The Position Of Young People In The Social Sharing Networks Within The Framework Of The New Media Age. (PhD Thesis), Marmara University, Turkey.

Kim, K. J., Sundar, S. S., \& Park, E. (2011). The effects of screen-size and communication modality on psychology of mobile device users. Proceedings of the 2011 Annual Conference Extended Abstracts on Human Factors in Computing Systems (CHI EA'11), 1207-1212. doi: 10.1145/1979742.1979749 
Lee, S. K., Lindsey, N. J., \& Kim, K. S. (2017). The effects of news consumption via social media and news informa tion overload on perceptions of journalistic norms and practices. Computers in Human Behavior, 75, 254-263. https://doi.org/10.1016/j.chb.2017.05.007

Ley, B., Ogonowski, C., Hess, J., Reichling, T., Wan, L., \& Wulf, V. (2014). Impacts of new technologies on media usage and social behavior in domestic environments. Behaviour and information technology, 33(8), 815-825.

Lull, J. (1991). Inside family viewing: ethnographic research on television's audiences. London, UK: Routledge.

Marczyk, G., DeMatteo, D., \& Festinger, D. (2005). Essentials of Research Design and Methodology. Hobo ken, NJ: John Wiley \& Sons.

Nauman, S., I. (2017). News Usage Practices of Pakistani University Students in the Networked News Environment. University of Stirling: UK.

Odongo, B. D., (2012). Human Rights and Media in Uganda; A critical Analysis of the Mass Media Freedom (Master's Thesis). University of Göteborg, Sweden.

Papacharissi, Z., \& Mendelson, A. M. (2007). An exploratory study of reality appeal: Uses and gratification of reality TV shows. Journal of Broadcasting \& Electronic Media, 52, 355-370. doi: $10.1080 / 08838150701307152$

Perry, D. K. (2002). Theory and Research in Mass Communication: Contexts and Consequences (2nd ed.). Mahwah, New Jersey: Lawrence Erlbaum Associates.

Raacke, J., \& Bonds-Raacke, J. (2008). Myspace and Facebook: Applying the uses and gratification theory to exploring friend-networking sites. Cyberpsychology \& Behaviour, 169-174. doi: 10.1089/cpb.2007.0056

Rubin, A.M. (1981). An examination of television viewing motives. Communication Research, 8, $141-165$.

Ruggiero, T. E. (2000). Uses and gratifications theory in the 21st century. Mass Communication \& Society, 3, 3-37. doi: 10.1207/S15327825MCS0301_02

Smith, S.M. and Krugman, D.M., (2010). Exploring perceptions and usage patterns of digital video recorder owners. Journal of Broadcasting \& Electronic Media, 54 (2),248-264.

So, J. (2012). Uses, gratifications, and beyond: Toward a model of motivated media exposure and its effects on risk perception. Communication Theory, 22, 116-137. doi: 10.1111/j.1468-2885.2012. 01400.x

Sundar, S. S., \& Limperos, A., M. (2013) Uses and Grats 2.0: New Gratifications for New Media, Journal of Broadcasting \& Electronic Media, 57:4, 504-525, DOI: 10.1080/08838151.2013.845827

Swart, J., Peters, C., \& Broersma, M. (2016). Navigating cross-media news use: Media repertoires and the value of news in everyday life. Journalism Studies, (ahead-of-print), doi:10.1080/1461670X.2015.1129285. 
Thompson, B. (2004). Exploratory and Confirmatory Factor Analysis: Understanding Concepts and Applications. American Psychological Association, Washington, DC.

UCC (2017, May, 01). Quarterly statistics on key communications indicators as of Dec 2016. Uganda Communications Commission. Retrieved from http://www.ucc.co.ug/files/down loads/Quarterly Statistics_on_Key_Communications_Indicators_as_of_Dec_2016.pdf

Wei, R., \& Lo, V. (2006). Staying connected while on the move: Cell Phone use and social connectedness. New Media \& Society, 8, 53-72. doi: 10.117/1461444806059870

West, R., \& Turner, L. H. (2010). Introducing Communication Theory Analysis and Application (4th ed.). New York: McGraw-Hill.

Westerman, D., Spence, P., \& Van Der Heide, B. (2014). Social media as information source: Recency of updates and credibility of information. Journal of Computer- Mediated Communication, 19(2), 171e183.

Zeng, L. (2011). More than audio on the go: Uses and gratifications of MP3 players. Communication Research Reports, 28, 97-108. doi 